\title{
The Effect of Wind and Temperature on the Spread of Crude Oil Spill on Niger Delta Coastline
}

\author{
J.O.C. Eluma ${ }^{1}$, K.O. Okpala ${ }^{2}$, E.E. Effiong ${ }^{3}$, O.E. Onyelucheya ${ }^{4}$ \\ Department of Chemical Engineering, Federal University of Technology, P.M.B. 1526, Owerri, Nigeria
}

\begin{abstract}
The effects of wind induced velocity and Temperature, on the transport of oil spill on water is considered and appropriate temperature and wave-driven equation is coupled that is capable of enhancing the accuracy of the oil spill model. By applying wind and tidal velocity principles together with Temperature variation effects to the governing equation, the spread behaviour can be better predicted. The knowledge of the trajectory followed by an oil slick spilled on the coastline is valuable in the estimation of potential risks and in combating the pollution using floating barriers, detergents, etc. In order to estimate these slicks trajectories an improved model, based on mass and momentum conservation equations is needed. The result from this work will better predict that incorporation of these parameters into the model causes the oil spill to get to the shore line a few hours earlier than when these parameters were ignored.
\end{abstract}

Keywords: Niger delta; coastline; Spreading; Oil spill;; Oil pollution;; wind; Crude Oil properties

\section{Introduction}

Nigeria is bordered to the North by the Republics of Niger and Chad, to the West by the Republic of Benin, to the East by the Republic of Cameroon and to the South by the Atlantic Ocean (Dublin Green et al, 1999). Nigeria has a coastline of approximately $853 \mathrm{~km}$ facing the Atlantic Ocean. This coastline lies between latitude $4^{\circ} 10^{\text {ec }}$ to $6^{\circ} 20^{\circ} \mathrm{N}$ and longitude $2^{\circ} 45^{\text {ec }}$ to $8^{\circ} 35^{\text {ce }} \mathrm{E}$. Figure 1 below is the Map of the Niger Delta Coastline.

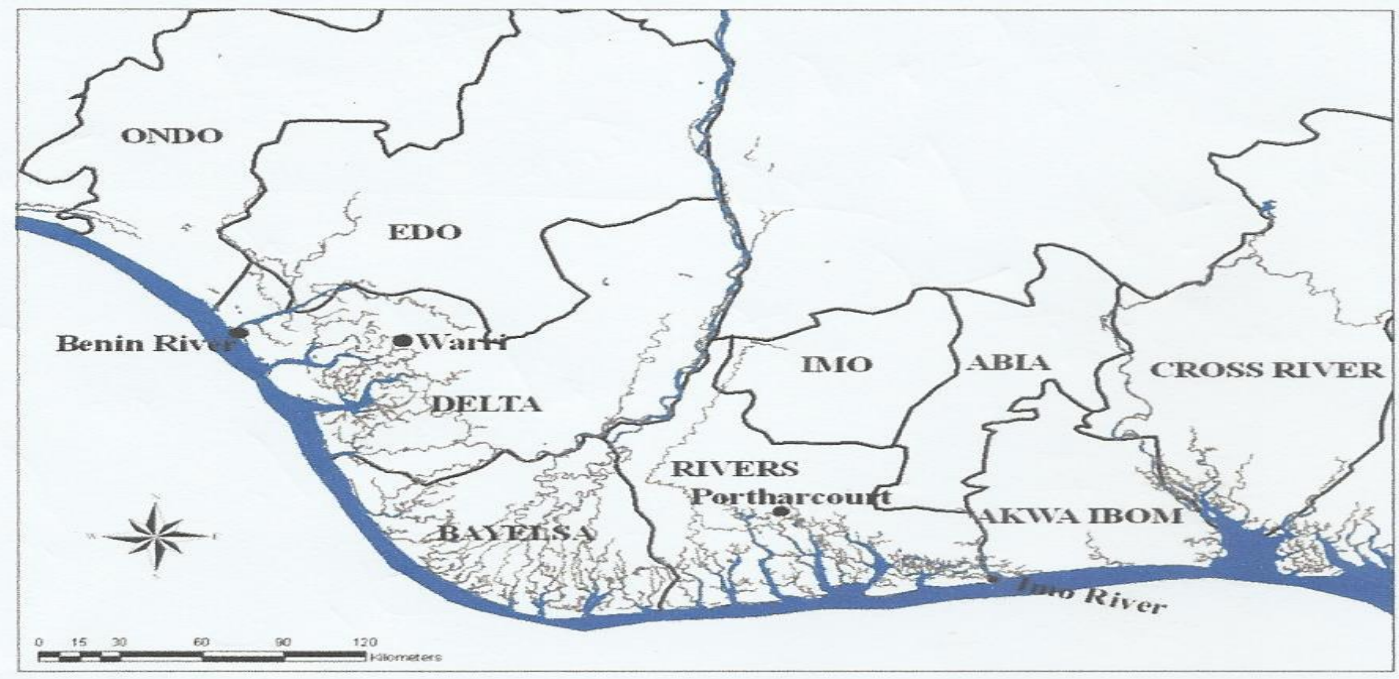

Figure 1: Map of the Niger Delta Coastline

The Nigerian coastline experiences mainly the south westerly winds which are onshore and confined generally to azimuths of $215^{\circ}-266^{\circ}$ with velocities of $2-5 \mathrm{~m} / \mathrm{s}$. During the rainy season, wind speed increases to about $10 \mathrm{~m} / \mathrm{s}$ especially during heavy rain falls and thunderstorms. Temperatures in the coastal areas are moderated by the cloud cover and by the generally damp air. However, mean monthly temperature vary between $24 \mathrm{o} \mathrm{C}$ and $32 \mathrm{o} \mathrm{C}$ throughout the year.

The surface water of the Nigerian coast is basically warm with temperature generally greater than $24^{\circ} \mathrm{C}$. Sea surface temperatures show double peaked cycles, which match quantitatively the cycle of solar heights. Between October and May, Sea surface temperatures range from $27^{\circ}-28^{\circ} \mathrm{C}$, while during the rainy season of June to October; the range is between $24^{\circ}$ and $25^{\circ} \mathrm{C}$. (Dublin Green et al, 1999). The surface water is typically oceanic surface water of the Gulf of Guinea with salinity generally less than $35.00 \%$. (Dublin Green et al, 1999).

Oil spillage is a major environmental problem in Nigeria. Between 1976 and 1996 Nigeria recorded a total of 4835 oil spill incidents, which resulted in a loss of $1,896,960$ barrels of oil to the environment. In 1998, 40,000 barrels of oil from Mobil platform off the Akwa Ibom coast were spilt into the environment causing severe damage to the coastal environment. Oil spillage has led to very serious pollution and destruction of flora, fauna and resort centers, pollution of drinkable water, destruction of properties and lives along the Nigerian coast. Oil spillage has also caused regional crisis in the Niger Delta. Factors responsible for oil spillage in the zone are; corrosion of oil pipes and tanks sabotage, 


\section{International Journal of Science and Research (IJSR) \\ ISSN (Online): 2319-7064}

Index Copernicus Value (2013): 6.14 | Impact Factor (2015): 6.391

port operations and inadequate care in oil production operations and engineering drills. Waves, wind drift current, tidal current, ocean currents, bathymetry, vegetation and topography influence oil spill dispersal along the Nigerian coastal waters. Oil spill dispersal can be managed by using oil spill trajectory and fate models, oil booms and mops, surfactant chemicals, oil skimmers, absorbents and gels. $[2][3][4][6][9][11]$.

The effect of wind/tidal currents and temperature are coupled into model that could predict oil spread rate to a higher degree of accuracy based on the physical characteristics of the oil and the aquatic medium, such as viscosity, density, surface tension; the volume of oil discharged into the sea; the spreading rate force and will be presented.

\section{Materials and Method}

The development of equations for determining the spread of petroleum spill and the coefficient of spread on the aquatic environment is essential for its containment ${ }^{[5]}$.

$\mathrm{L}=\left[11.23-1.07\left(\mu_{\mathrm{p}} / \mu_{\mathrm{w}}\right)+0.33 \mathrm{~V}_{\mathrm{p}}\right] \mathrm{t}^{0.87[14]}(1)$

Equation (1) is made more practicable by incorporating other functional parameters.

Improvement on the model by incorporation of Windinduced Velocity of Spread

The effect of wind on the velocity of spreading is considered.

Assumptions:

(a) The ambient water temperature is constant and above the pour point of oil.

(b) Oil spill moves at $3.4 \%$ of the wind speed. ${ }^{[16]}$

Let the wind velocity at time, $\mathrm{t}=0$, in a certain horizontal direction $w$ on the water surface be $\mathrm{S}_{\mathrm{w}}(\mathrm{m} / \mathrm{s})$, then after a time, $t$, of oil spill, the velocity of the moving oil spill in this direction, (or the effective wind velocity), $\mathrm{E}_{\mathrm{w}}(\mathrm{m} / \mathrm{s})$ is given as: ${ }^{[16]}$

$$
\mathrm{E}_{\mathrm{w}}=0.034 \mathrm{~S}_{\mathrm{w}}
$$

At time, $\mathrm{t}=\mathrm{T}$, after the oil spill, the total distance, $\mathrm{L}$ travelled by the spilled oil is given by:

$$
\mathrm{L}=\mathrm{E}_{\mathrm{w}} \mathrm{T}=0.034 \mathrm{~S}_{\mathrm{w}} \mathrm{T}
$$

Let $A_{c}(\mathrm{~m} / \mathrm{s})$, be the average surface current.

If the average surface current is significant enough, the magnitude and direction of the oil spill will be determined by the resultant effect of $E_{w}$ and $A_{c}$

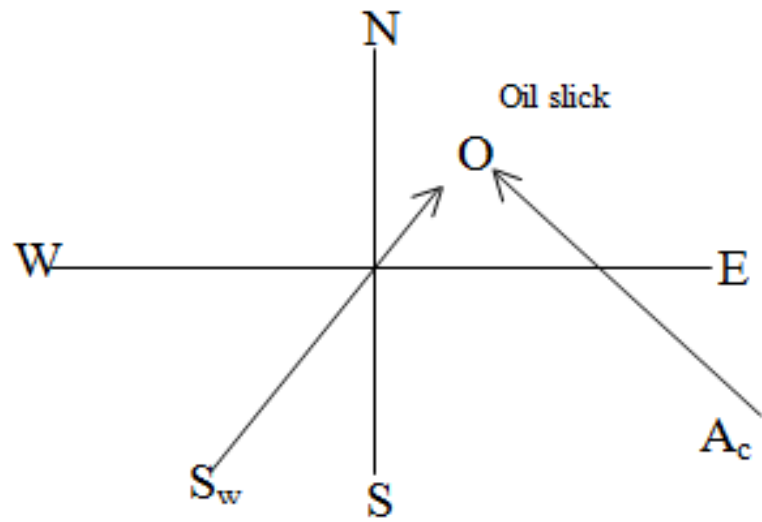

Figure 2: Illustration of wind currents

Assuming that the oil spill is moving from a South West, $\mathrm{SW}$, direction with a speed of $\mathrm{S}_{\mathrm{w}}$.

Suppose that there is an average surface current $A_{c}$ moving from the South East, SE, direction, as illustrated in figure (2). Both $\mathbf{S}_{\mathbf{w}}$ and $\mathbf{A}_{\mathbf{c}}$ separately have two velocity components, $\mathrm{x}$ and $\mathrm{y}$. To obtain the resultant of the two vectors, the components of the two velocities along the $\mathrm{x}$ and $y$ directions have to be resolved as illustrated in figure (3) below:

(a)

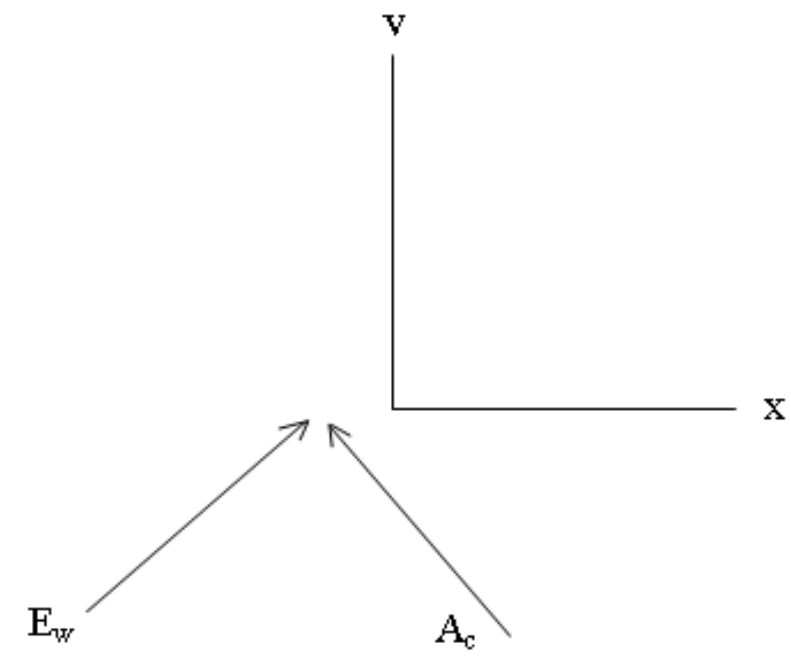

(b)



(c)

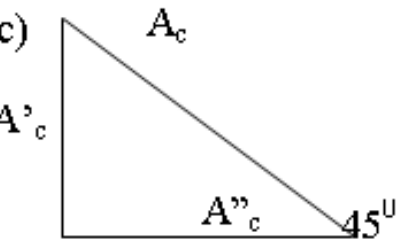

Figure 3: Illustration of velocity components

Volume 5 Issue 7, July 2016 www.ijsr.net

Licensed Under Creative Commons Attribution CC BY 


\section{International Journal of Science and Research (IJSR) \\ ISSN (Online): 2319-7064 \\ Index Copernicus Value (2013): 6.14 | Impact Factor (2015): 6.391}

$\mathbf{E}_{\mathbf{w}}$ has components $\mathbf{E}^{\prime}$ w and $\mathbf{E}^{\prime}{ }^{\text {w' }}$, while $\mathbf{A}_{\mathbf{c}}$ has components $\mathbf{A}_{\mathbf{c}}$ and $\mathbf{A}_{\mathbf{c}}$ as shown in figure (2) above. Considering figure (3)(b)

By resolving the velocity components using trigonometric applications:

$$
\mathrm{E}_{\mathrm{w}}=\left(0.034 \mathrm{~S}_{\mathrm{w}}\right) \operatorname{Cos} 45^{0}+\left(0.034 \mathrm{~S}_{\mathrm{w}}\right) \operatorname{Sin} 45^{0}
$$

But from Pythagoras rule:

$$
\begin{gathered}
\mathrm{E}_{\mathrm{w}}{ }^{2}=\mathrm{E}_{\mathrm{w}}^{\mathrm{ee}}+\mathrm{E}_{\mathrm{w}}{ }^{2} \\
\mathrm{E}_{\mathrm{w}}{ }^{2}=\left(\left(0.034 \mathrm{~S}_{\mathrm{w}}\right) \operatorname{Cos} 45^{0}\right)^{2}+\left(\left(0.034 \mathrm{~S}_{\mathrm{w}}\right) \operatorname{Sin} 45^{0}\right)^{2} \\
\mathbf{E}_{\mathbf{w}}=\operatorname{SQRT}\left(\left(\left(0.034 \mathrm{~S}_{\mathrm{w}}\right) \operatorname{Cos} 45^{0}\right)^{2}+\left(\left(0.034 \mathrm{~S}_{\mathrm{w}}\right) \operatorname{Sin} 45^{0}\right)^{2}\right)
\end{gathered}
$$

Similarly, considering figure (2)(c)

The vector $\mathbf{A}_{\mathbf{c}}$ can be resolved into two components such that:

$$
\mathbf{A}_{\mathbf{c}}=\mathbf{A}_{\mathbf{c}} \operatorname{Cos} 315^{\circ}+\mathbf{A}_{\mathbf{c}}{ }_{\mathbf{c}} \operatorname{Sin} 315^{0}
$$

The final average surface current $A_{c}$ influencing the effective wind velocity is obtained as:

$$
A_{c}=\operatorname{SQRT}\left(\left(A^{c e} \operatorname{Cos} 315^{0}\right)^{2}+\left(A{ }_{c}{ }_{c} \operatorname{Sin} 315^{0}\right)^{2}\right)
$$

However, the combined effect of equations (7) and (9) contribute to the significant velocity of spread of the spill. If, as envisaged earlier, that the combined effect is represented now in figure (4) below:

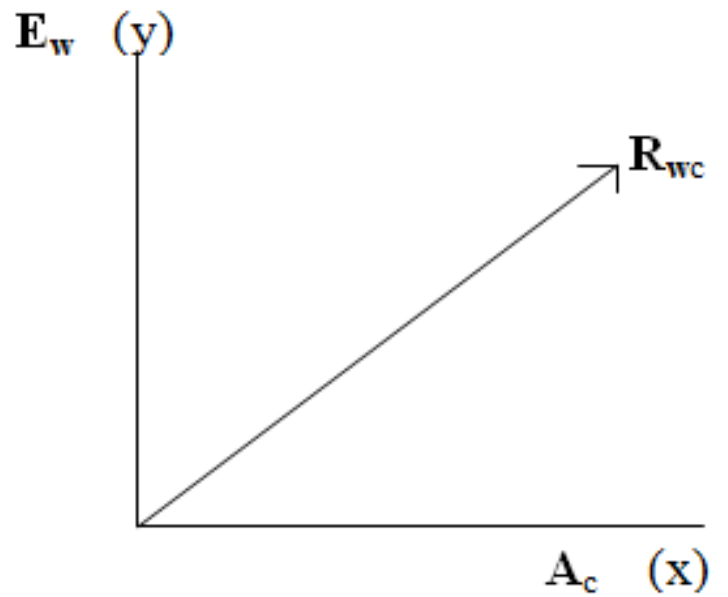

Figure 4: Illustration of combined velocities and resultant.

Let $\mathbf{R}_{\mathbf{w c}}$ be the resultant of the two velocities, $\mathbf{E}_{\mathbf{w}}$ and $\mathbf{A}_{\mathbf{c}}$ moving now from an angle, $\theta_{\mathrm{wc}}$

$$
\begin{array}{r}
\mathbf{R}_{\mathrm{wc}}{ }^{2}=\mathbf{E}_{\mathrm{w}}{ }^{2}+\mathbf{A}_{\mathrm{c}}{ }^{2}(10) \\
\mathrm{R}_{\mathrm{wc}}{ }^{2}=\left(\left(0.034 \mathrm{~S}_{\mathrm{w}} \operatorname{Cos} 45^{0}\right)+\left(0.034 \mathrm{~S}_{\mathrm{w}} \operatorname{Sin} 45^{0}\right)\right)^{2}+\left(\left(\mathrm{A}_{\mathrm{c}}^{\text {ec }} \operatorname{Cos}\right.\right. \\
\left.\left.315^{0}\right)+\left(\mathrm{A}^{\prime{ }_{\mathrm{c}}} \operatorname{Sin} 315^{0}\right)\right)^{2}(11)
\end{array}
$$

So that the velocity $\mathbf{R}_{\mathbf{w c}}(\mathrm{m} / \mathrm{s})$, is given as:

$\mathbf{R}_{\mathrm{wc}}(\mathrm{m} / \mathrm{s})=\operatorname{SQRT}\left(\left(\left(0.034 \mathrm{~S}_{\mathrm{w}}\left(\operatorname{Cos} 45^{0}+\operatorname{Sin} 45^{0}\right)\right)^{2}+\left(\mathrm{A}_{\mathrm{c}}\right.\right.\right.$ $\left.\left.\left(\operatorname{Cos} 315^{0}+\operatorname{Sin} 315^{0}\right)^{2}\right)\right)(12)$ Equation (12) is the velocity at which the oil spill is moving in the forward direction on the water surface at constant temperature. It is possible to have a directly opposing density current in form of drag wind velocity, $\mathbf{D}_{\mathbf{w}}$, moving from the same angle as equation (12) above but in opposite direction.

The Drag wind velocity for a unit area is given as: ${ }^{[17]}$

$$
\begin{gathered}
\mathrm{D}_{\mathrm{w}}=\mathrm{V}_{\mathrm{p}} \tau_{\mathrm{p}} \mathrm{E}_{\mathrm{w}}^{1.8} \\
\text { Where, } \tau_{\mathrm{p}}=0.029\left(\mu_{\mathrm{p}} \mu_{\mathrm{w}}\right)^{2}
\end{gathered}
$$

The final wind velocity $\mathbf{U}_{\mathbf{w c}}$ of the spread of the oil spill on the water surface under this condition can be represented by:

Hence,

$$
\mathbf{U}_{\mathrm{wc}}=\mathbf{R}_{\mathrm{wc}}-\mathbf{D}_{\mathrm{w}}
$$

$\mathbf{U}_{\mathbf{w c}}(\mathrm{m} / \mathrm{s})=\operatorname{SQRT}\left[\left(0.034 \mathrm{~S}_{\mathrm{w}}\left(\operatorname{Cos} 45^{0}+\operatorname{Sin} 45^{0}\right)\right)^{2}+\left(\mathrm{A}_{\mathrm{c}}\right.\right.$ $\left.\left.\left(\operatorname{Cos} 315^{0}+\operatorname{Sin} 315^{0}\right)^{2}\right)\right]-\left(0.029 \mathrm{~V}_{\mathrm{p}}\left(\mu_{\mathrm{p}} \mu_{\mathrm{w}}\right)^{2} \mathrm{E}_{\mathrm{w}}^{1.8}\right)^{2}(16)$ $\mathbf{U}_{\mathbf{w c}}(\mathrm{m} / \mathrm{s})=\left[\left(0.0023 \mathrm{~S}_{\mathrm{w}}{ }^{2}+1.4142 \mathrm{~A}_{\mathrm{c}}{ }^{2}\right)^{1 / 2}-\left(\left(0.029 \mathrm{~V}_{\mathrm{p}}\left(\mu_{\mathrm{p}} \mu_{\mathrm{w}}\right)^{2}\right.\right.\right.$ $\left.\left.\left.\mathrm{E}_{\mathrm{w}}^{1.8}\right)^{2}\right)\right](17)$

Where $\mathbf{U}_{\mathbf{w c}}(\mathrm{m} / \mathrm{s})$ is the final wind velocity.

Equation (17) is greatly affected by the functional parameters of the oil, such density, viscosity, surface tension, quantity of oil spilled and the fluid regime. ${ }^{[11]}$

A directional wind is acting on the viscosity, surface tension and spreading coefficient according to the relationship: ${ }^{[11][18]}$ $\mathrm{U}=\left\{\left[4 \mathrm{~g}\left(\rho_{\mathrm{w}}-\rho_{\mathrm{p}}\right) \sigma_{\mathrm{w}} \sigma_{\mathrm{p}}\right] /\left[3 \mathrm{~K} \rho_{\mathrm{w}} \mu_{\mathrm{w}}\right]\right\}^{1 / 2}(18)$

$\mu_{\mathrm{w}}=\left[4 \mathrm{~g}\left(\rho_{\mathrm{w}}-\rho_{\mathrm{p}}\right)\left(\sigma_{\mathrm{w}} \sigma_{\mathrm{p}}\right) /\left[3 \mathrm{~K} \rho_{\mathrm{w}} \mathrm{U}^{2}\right](19)\right.$

Substituting equation (19) into Equation (1) gives: $\mathrm{L}=\left[11.23-\left\{1.07\left[3 \mathrm{~K} \mu_{\mathrm{p}} \rho_{\mathrm{w}} \mathrm{U}^{2}\right]\right\} /\left\{\left[4 \mathrm{~g}\left(\rho_{\mathrm{w}}-\rho_{\mathrm{p}}\right)\left(\sigma_{\mathrm{w}} \sigma_{\mathrm{p}}\right)\right]\right\}+\right.$ $\left.0.33 \mathrm{~V}_{\mathrm{p}}\right] \mathrm{t}^{0.87}(20)$ Assuming that:

(a) The slick is one continous layer floating on the water surface.

(b) Physical and Chemical changes such as evaporation are neglected.

(c) The only change that the spill can undergo is movement from one place to another.

$\mathrm{L}=\left[11.23-\left\{1.07\left[3 \mathrm{~K} \mu_{\mathrm{p}} \rho_{\mathrm{w}} \mathrm{U}_{\mathrm{wc}}{ }^{2}\right]\right\} /\left\{\left[4 \mathrm{~g}\left(\rho_{\mathrm{w}}-\rho_{\mathrm{p}}\right)\left(\sigma_{\mathrm{w}} \sigma_{\mathrm{p}}\right)\right]\right\}+\right.$ $\left.0.33 \mathrm{~V}_{\mathrm{p}}\right] \mathrm{t}^{0.87}(21)$

Where $U_{w c}$ is the final wind velocity.

By substituting Equation (17) in Equation (21) gives: $\mathrm{L}=\left\{11.23-1.07\left[3 \mathrm{~K} \mu_{\mathrm{p}} \rho_{\mathrm{w}}\left[\left(0.0023 \mathrm{~S}_{\mathrm{w}}{ }^{2}+1.4142 \mathrm{~A}_{\mathrm{c}}{ }^{2}\right)^{1 / 2}-\right.\right.\right.$ $\left.\left(\left(0.029 \mathrm{~V}_{\mathrm{p}}\left(\mu_{\mathrm{p}} \mu_{\mathrm{w}}\right)^{2} \mathrm{E}_{\mathrm{w}}{ }^{1.8}\right)^{2}\right)^{1 / 2}\right] /$

$$
\left.\left.\left[4 \mathrm{~g}\left(\rho_{\mathrm{w}}-\rho_{\mathrm{p}}\right)\left(\sigma_{\mathrm{w}} \sigma_{\mathrm{p}}\right)\right]\right]+0.33 \mathrm{~V}_{\mathrm{p}}\right\} \mathrm{t}^{0.87}(22)
$$

The oil spill will be moving in the direction, $\theta_{\text {wc" }}$ such that $\tan \theta_{\mathrm{wc}}=\left(\mathrm{A}_{\mathrm{c}}\left(\operatorname{Cos} 315^{\circ}+\operatorname{Sin} 315^{\circ}\right)\right) /\left(0.034 \mathrm{~S}_{\mathrm{w}}\left(\operatorname{Cos} 45^{0}\right.\right.$ $\left.\left.+\operatorname{Sin} 45^{\circ}\right)\right)(23)$

$\theta_{\mathrm{wc}}=\tan ^{-1}\left(1.4142 \mathrm{~A}_{\mathrm{c}}\right) /\left(0.0481 \mathrm{~S}_{\mathrm{w}}\right)(24)$

\section{Incorporation of Temperature on the spread behaviour:}

The effect of changes in Temperature on the spread through the viscosity is considered and the result incorporated into the equation. This is so because fluids run faster when they experience increase in temperature. When water mixes with water, an emulsion is formed, viscosity variation due to emulsion formation alters the prediction of spread and can be taken into account.

The final correlation of variation in terms of temperature change is expressed as follows ${ }^{[20]}$ :

$\mu_{\mathrm{p}}=\mu_{\mathrm{pi}} \operatorname{Exp}\left[\left(\mathrm{C}_{\mathrm{v}} \mathrm{F}_{\mathrm{em}} / 1-\mathrm{C}_{\mathrm{m}} \mathrm{F}_{\mathrm{em}}\right)+\mathrm{C}_{\mathrm{e}} \mathrm{F}_{\mathrm{ev}}+\mathrm{C}_{\mathrm{T}}\left\{\left(1 / \mathrm{T}-1 / \mathrm{T}_{0}\right\}\right]\right.$

$$
\begin{aligned}
& \mu_{\mathrm{p}}=\mu_{\mathrm{pi}} \operatorname{Exp}[\varphi](26) \\
& \varphi=\left[\left(\mathrm{C}_{\mathrm{v}} \mathrm{F}_{\mathrm{em}} / 1-\mathrm{C}_{\mathrm{m}} \mathrm{F}_{\mathrm{em}}\right)+\mathrm{C}_{\mathrm{e}} \mathrm{F}_{\mathrm{ev}}+\mathrm{C}_{\mathrm{T}}\left\{\left(1 / \mathrm{T}-1 / \mathrm{T}_{0}\right\}\right](27)\right. \\
& \text { Where: }
\end{aligned}
$$




\section{International Journal of Science and Research (IJSR) \\ ISSN (Online): 2319-7064}

Index Copernicus Value (2013): 6.14 | Impact Factor (2015): 6.391

$\mathrm{T}_{0}$ is the initial temperature,

$\mu_{\mathrm{pi}}$ is the initial oil viscosity (K),

$\mathrm{C}_{\mathrm{v}}, \mathrm{C}_{\mathrm{m}}, \mathrm{C}_{\mathrm{T}}$ are empirical constants.

$\mathrm{C}_{\mathrm{v}}=2.5^{[20][21]}$

$\mathrm{C}_{\mathrm{m}}=0.65$

$\mathrm{C}_{\mathrm{e}}$ varies from 1 for crude oils to 10 for refined oils,

(Mackay and Mooney, (1991)

$\mathrm{F}_{\mathrm{em}}$ is the water volume fraction.

$\mathrm{F}_{\mathrm{ev}}$ is the final water volume due to evaporation depending on the oil type and is assumed to be 0.7

for crude oil and 0.25 for refined oils. ${ }^{[20]}$

At hot seasons and times (given as10.00 hours to 17:00hours [22]

Equation (25) is rewritten as:

$\mu_{\mathrm{p}}=\mu_{\mathrm{pi}} \operatorname{Exp}\left[\left(2.5 \mathrm{~F}_{\mathrm{em}} / 1-0.65 \mathrm{~F}_{\mathrm{em}}\right)+0.7 \mathrm{C}_{\mathrm{e}}+5.0\left\{\left(1 / \mathrm{T}-1 / \mathrm{T}_{0}\right\}\right]\right.$

(28)

At cold seasons and cold times (given as from 17:00hours to 10:00hours; ${ }^{[22]}$

$\mathrm{T}_{0}=\mathrm{T} ; \mathrm{F}_{\mathrm{ev}}=0 ; \mathrm{F}_{\mathrm{em}}=0$ (29)

Equation (25) reduces to:

$\mu_{\mathrm{p}}=\mu_{\mathrm{pi}} \operatorname{Exp}[0]$ (30)

Such that,

$\mu_{\mathrm{p}}=\mu_{\mathrm{pi}}(31)$

The extent of spread for the two weather conditions are as follows:

For hot season: ${ }^{[22][23]}$

Substituting Equation (26) into Equation (22) gives:

$\mathrm{L}=\left[11.23-1.07\left[3 \mathrm{~K} \mu \operatorname{piExp}[\varphi] \rho_{\mathrm{w}}\left[\left(0.0023 \mathrm{~S}_{\mathrm{w}}{ }^{2}+1.4142 \mathrm{~A}_{\mathrm{c}}{ }^{2}\right)^{1 / 2}\right.\right.\right.$

$\left.\left.\left(\left(0.029 \mathrm{~V}_{\mathrm{p}}\left(\mu \mathrm{piExp}[\varphi] \mu_{\mathrm{w}}\right)^{2} \mathrm{E}_{\mathrm{w}}^{1.8}\right)^{2}\right)^{1 / 2}\right]\right] /\left[4 \mathrm{~g}\left(\rho_{\mathrm{w}}-\rho_{\mathrm{p}}\right)\left(\sigma_{\mathrm{w}} \sigma_{\mathrm{p}}\right)\right]+$ $\left.0.33 \mathrm{~V}_{\mathrm{p}}\right] \mathrm{t}^{0.87}(32)$

For Cold season: ${ }^{[22][23]}$

Equation (22) applies, hence:

$\mathrm{L}=\left[11.23-1.07\left\{3 \mathrm{~K} \mu_{\mathrm{p}} \rho_{\mathrm{w}}\left[\left(0.0023 \mathrm{~S}_{\mathrm{w}}{ }^{2}+1.4142 \mathrm{~A}_{\mathrm{c}}{ }^{2}\right)^{1 / 2}-\right.\right.\right.$ $\left.\left(\left(0.029 \mathrm{~V}_{\mathrm{p}}\left(\mu_{\mathrm{p}} \mu_{\mathrm{w}}\right)^{2} \mathrm{E}_{\mathrm{w}}^{1.8}\right)^{2}\right)^{1 / 2}\right] /$

$\left.\left.\left[4 \mathrm{~g}\left(\rho_{\mathrm{w}}-\rho_{\mathrm{p}}\right)\left(\sigma_{\mathrm{w}} \sigma_{\mathrm{p}}\right)\right]\right\}+0.33 \mathrm{~V}_{\mathrm{p}}\right] \mathrm{t}^{0.87}(33)$

\section{Results And Discussions}

The major difference of this model, as compared to other used semi-empirical models, is that this model is more generalized by the inclusion of the effects of wind, temperature, other functional parameters This feature increases compatibility of the oil spill model with the modern hydrodynamics, meteorological and ecological models. Another advantage of the model lies on the use of only physically relevant parameters whenever possible to increase a range of model application for different spill scenarios and environmental conditions. While Fay [6], based his work on correlation and regression technique, the present work was based on computer simulation which is cheaper in the long run and easier to implement.

From the relationships of the model equations, it is important to note that the extent of spread, especially on wind induced environment is dependent on the physical properties of petroleum and the aquatic environment, the quantity of petroleum spilled and the final wind velocity occasioning the spread.

The spreading coefficient remains constant with change in time and surface wind velocity, $S_{w}$. The surface wind velocity obviously affects the distance of spread and kinematic momentum rate but does not affect the final velocity significantly. The final velocity and distance is affected by the area. A change in the average surface current has great effect on the velocity and distance.

It is noted that the difference between the values forward spill velocity $R_{w c}$, and final velocity, $U_{w c}$, are negligible, apparently because the drag wind velocity itself is also negligible.

The model equation justifies that the major factor which moves oil spill on sea, is the tidal current. Figure (5) is the illustration of longshore wind current direction along the Nigeria coastline. Figures (6) and (7) are the illustration of oil spill trajectories in hot and cold seasons.

The model agreed with the semi-analytical solution of Fay (1971). The oil spill equation can be used to assess the expected fate of Nigeria light crude oil that may be spilled during oil operations in Niger delta Coastal water. It can be used to critically assess the fate of oil released during any scenario. 


\section{International Journal of Science and Research (IJSR) \\ ISSN (Online): 2319-7064}

Index Copernicus Value (2013): 6.14 | Impact Factor (2015): 6.391

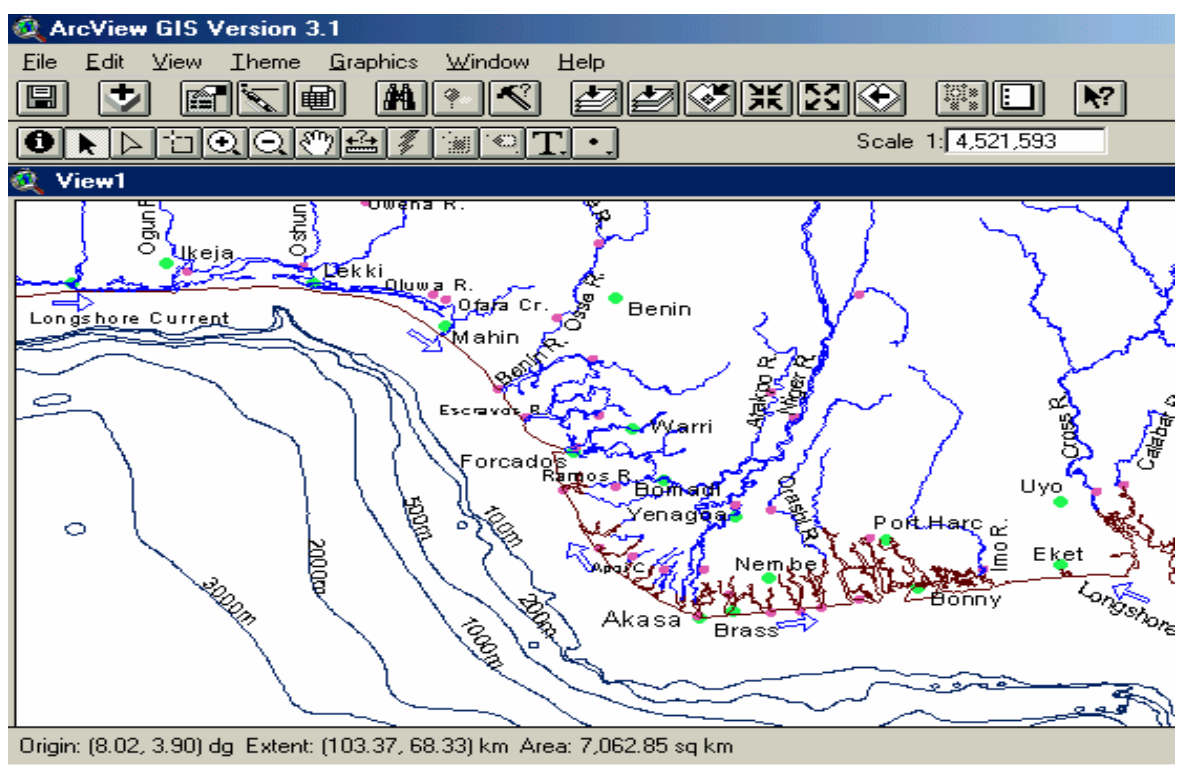

Figure 5: Longshore Current Directions along Nigerian Coastline

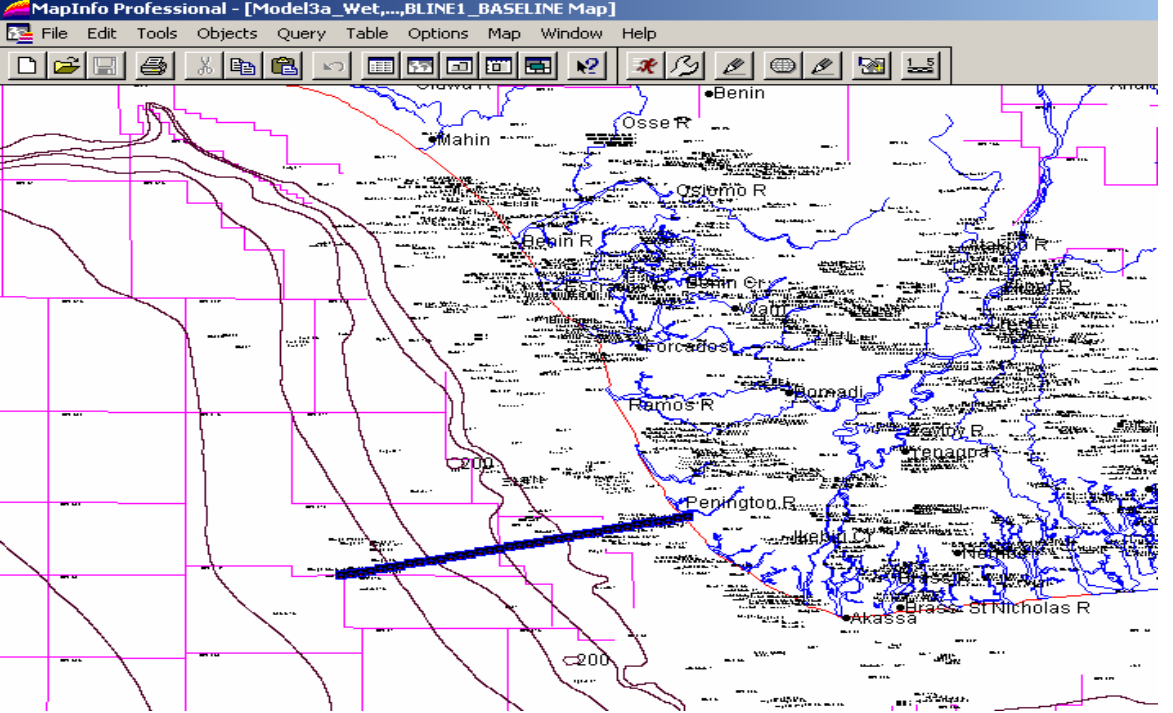

Figure 6: Oil Spill Trajectory for the hot/Wet Season

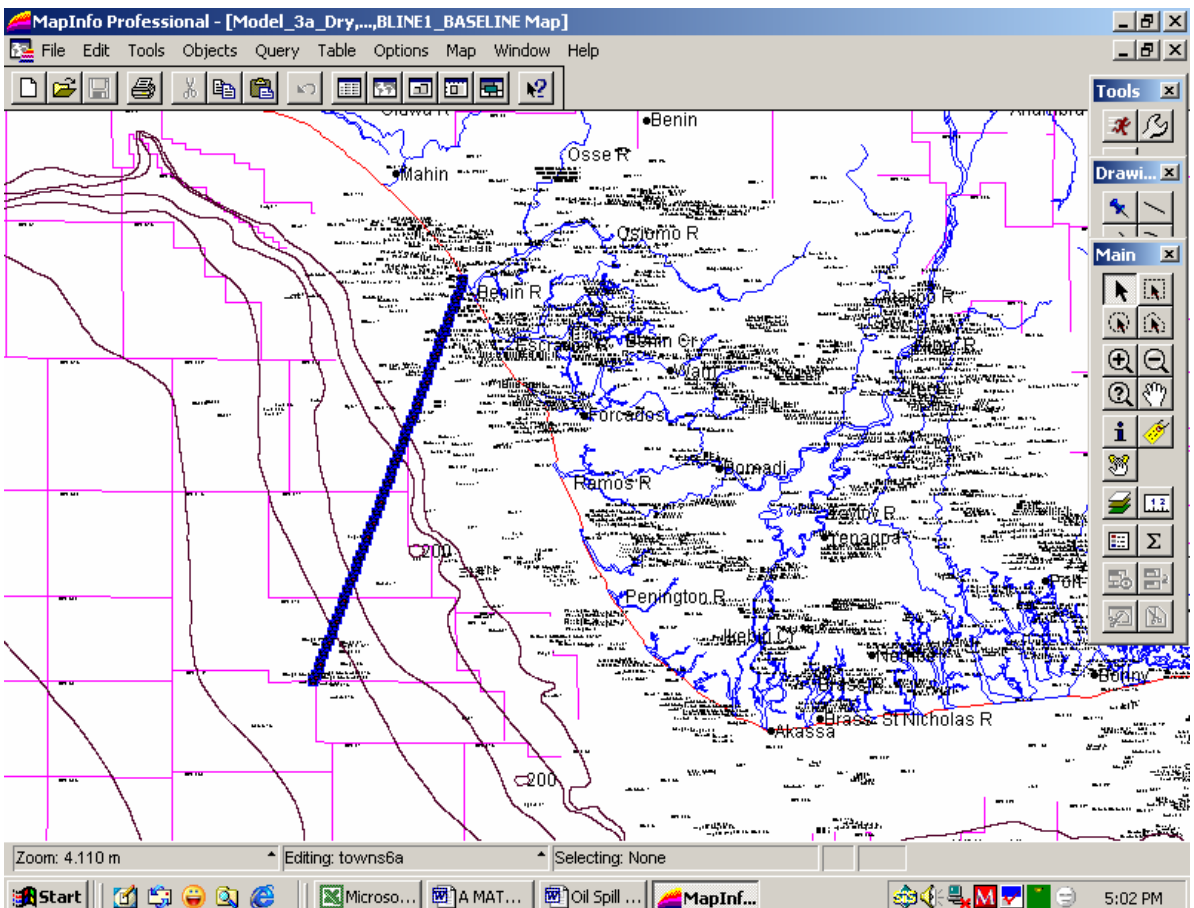

Figure 7: Oil Spill Trajectory for the Harmattan/Dry Season

Volume 5 Issue 7, July 2016 www.ijsr.net

Licensed Under Creative Commons Attribution CC BY 


\section{International Journal of Science and Research (IJSR)

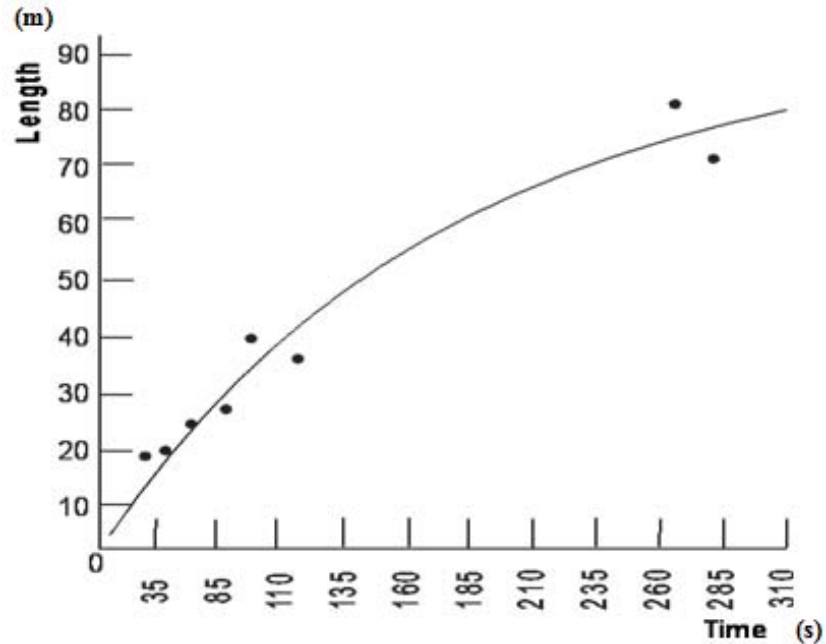

Figure 8: Plot of Length of Spread (m) against time (s)



Figure 9: Comparative Analysis of experimental determined Extent of Spread, Fayes Model and the Developed Model for Predicting the Extent of Spread

\section{Conclusion}

The effect of wind and temperature on the spread of crude oil on water is important for analysing or predicting the movement of spilled oil slick, due to growing concern over the increasing contamination of water bodies in our environment especially along the Niger Delta coastal lines. This is because any oil spill has a devastating and obvious effect on marine ecology. Crude oil when spilled on water commences various processes including spreading, and if unchecked and uncontrolled, can cause great environmental destruction to the affected areas. This paper presented a modified oil spill model which has been developed and couples effect of wind and temperature to predict oil spill movements on the sea. The effects of tidal currents and Eulerian wave drift were also considered in the model development and incorporation of the above factors relatively increased the accuracy of this model. (Badejo and Nwilo (2011).
The result from the model compares well with the laboratory data and the works of Fay ${ }^{[6] \cdot[14]}$.

The model can be used to simulate oil spills in order to assist pollution combat tasks in the Niger delta coastal line, so it is an important tool in any oil spill contingency plan

\section{References}

[1] Nduka,J.K., Obumselu, F.O. and Umedum, N.L. (2010). Crude Oil and Fractional Spillages Resulting from Exploration and Exploitation in Niger-Delta Region of Nigeria: A Review About the Environmental and Public Health Impact. www.intechopen.com

[2] AwobajoS.A.,(1981) "An Analysis of oil spill incidents in Nigeria" Proceedings of an International Seminar on the petroleum industry and the Nigerian Environment., 


\section{International Journal of Science and Research (IJSR) \\ ISSN (Online): 2319-7064}

Index Copernicus Value (2013): 6.14 | Impact Factor (2015): 6.391

Thompulos Environmntal pollution consultant publishers.(1981)

[3] Delvigne, G; Roelvink, J.; Sweeney, E. (1987) "Research on vertical turbulence dispersion of oil droplets and oiled particles: Literature review" NTIS REPORT 1987, No. PB87-101226/GAR.

[4] MacGregor, C.; Mclean, A.Y. (1977) "Fate of crude oil in a simulated arctic environment" pp. 461-463. In: Proceedings, Oil Spill Conference (March 8 -10, New Orleans, L.A). American Petroleum Institute Pub. No. 4284.

[5] Helen, M.; Lehr, W.; Cekirge, H. (1981) "Spreading, dispersion and evaporation of oil slicks in the Arabian Gulf Oil Spill Conference API.

[6] Fay, J.A. "Physical processes in the spread of oil on water surface" : Proc. Conf. on prevention and control of oil spills" API, Washington, D.C, 1970. pp 463-467; Conf. On prevention and control of oil spills API, EPA, and US Coast Guard, Washington, B.C.

[7] Adamson, (1967) Physical chemistry of surface interscience: New York 1967, 117 - 122 372-373.

[8] Fannelop, T.K.; Waldman, G. .D. (1971) "The dynamics of oil slicks or creeping crude" AIAA Paper, 1971, 71-14, AIAA 9th Aero space Sciences meeting .

[9] Buckmaster, (1973) "Viscous - gravity spreading of oil slick": J. Fluid Mech. 1973, 59:481-491.

[10] Cox and Foda, "Inputs, transport mechanisms and observed concentrations of petroleum in the marine environment" Academic Press, New York,1980, pp 91223.

[11] Motenson, P.C. "Spreading and evaporation of petroleum products on water" In: Proc. of the 9th Harbor Conference, Antwerp, 1974

[12] Al-Raber F. E, Cekirge A.H. Guney, N. „A stochastic simulation model of Oil spill fate and transport' Applied Mathematical Modelling, 2000, 13; 322 - 329.

[13] Susu A.A., Abowei M.F.N., Onyeme J.O.(1998) Oil Spills in Marine Environment, CJC Press Ltd Lagos, Nigeria, p. 499.

[14] Abowei M.F.N (1991)

[15]'Predictive Model Development for the simulation of Petroleum Weathering processes in Aquatic Environments', Ph.D thesis, Chemical Engineering, University of Lagos Nigeria, 1991, 51 - 61, 69 - 72.

[16](Fraga 1970) Hoult D.P., (1972) "Oil Spread on the Sea

[17] Nwilo, P.C. 'Oil Spill', causes, Impact, Solution Infotech today; 1998 Vol. 12 pp34.

[18] Liu, H.T.; Lin J.T. (1979) "Effects of an oil slick on wind waves" pp. 665-678. In: Proceedings of the 1979 Oil Spill Conference (Prevention, Behaviour, Control, Clean-up), Los Angeles.

[19]Le.hr, W.J.; Cekirge, H.M.; Fraga, R.J.; Belen. M.S. (1984). "Empirical studies of the spreading of oil spills" Oil and Petrochemical Pollut. 2: 7-11.

[20] Njobuenwu, D.O. and Abowei, M.F.N ,Spreading of Oil Spill on Placid Aquatic Mediume, http://1js.academicdirect.org/A12/011_024.htm

[21] Mackay, D, Mooney, J. (1991) ,Mass Transfer rates between oil slicks and watere, Can. J. Chem. Eng. 58, 569-574
[22] Mooney, J., (1961) „Handling viscosity and Temperature in emulsified oilec, National Conference on Control of environment

[23] API, EPA, LA

[24] Odogwu, G. (2014) Nigeria Institute of Meteorology, NIMET, Journal WxRev-wk21 May 2014

[25] NwiloP,C. and Badejo, O.T. (2005) Impacts and Management of Oil Spill Pollution along the Nigerian Coastal Areas. https://www.fig.net/pub/figpub/pub36/chapters/chapter 8.pdf 